\title{
PENDEKATAN MANAGEMENT CONFLICT UNTUK PERUBAHAN DAN PENGEMBANGAN ORGANISASI
}

\author{
Malikul Adil \\ Jurusan Teknik Industri \\ Universitas Muhammadiyah Gresik \\ Email : malikul_adil@hotmail.com
}

ABSTRACT

Q very manager these days face multifarious kinds of conflict problem, in their organization, In general people of Copinion that that conflict always generate negative impact. Though, certain in a condition exactly conflict need for the take of change and development of organization.

Beside conflict, every manager face also the problem of change that happened or which need initiation in their organization, so that the organization ever can accomodate with their environment, which by taking place time and also take to change. Development Problem also represent one of problem which must be solved by manager, because not only organizations have to be developed, but also human being in the organization require to also involve in development of organization, in order to effort face rival and environmental demand. Conflict - change - and development its intention of development of organization or development of organization in its word meaning other interconnected one another. Despitefully factors obliging the existence of change and also development of organization, also known and comprehended by contemporary manager, because development and also change represent a cycle 0f inheren of organization. Studying change conflict management - development, obliging us to also to comprehend psychological aspects, and aspects of sosiologis, beside economic aspects related to him.

Key words : conflict, change, development, psychological, sosiologis, economic.

\section{PENDAHULUAN .}

Setiap manajer dewasa ini menghadapi aneka macam problem konflik, di dalam organisasi mereka masing-masing.

Pada umumnya orang beranggapan bahwa konflik itu selalu menimbulkan dampak negatif. Padahal, dalam kondisi tertentu justru konflik perlu untuk kepentingan perubahan dan pengembangan organisasi.

Di samping konflik, setiap manajer menghadapi pula masalah perubahan yang terjadi atau yang perlu sosialisasi di dalam organisasi mereka, agar organisasi tersebut senantiasa dapat menyesuaikan dengan lingkungan mereka, yang dengan berlangsungnya waktu juga turut berubah.

Problem pengembangan juga merupakan salah satu problem pelik yang harus dipecahkan oleh para manajer, karena bukan saja organisasi-organisasi harus dikembangkan, tetapi pula manusia di dalam organisasi tersebut perlu pula diikutsertakan dalam pengembangan organisasi, dalam rangka usaha menghadapi pihak saingan dan tuntutan lingkungan.

Konflik - perubahan - dan pengembangan (maksudnya pengembangan organisatoris atau pengembangan organisasi dalam arti kata seluasluasnya) saling berkaitan satu sama lain.

Adanya konflik menuntut adanya perubahan dan pengembangan.

Perubahan dan pengembangan tidak dapat dilepaskan dari timbulnya aneka macam konflik.

Setiap manajer yang ingin memajukan organisasinya, harus memahami faktor-faktor apa saja yang menyebabkan timbulnya konflik, baik konflik di dalam individu maupun konflik antar perorangan dan konflik di dalam kelompok dan konflik antar kelompok.

Pemahaman faktor-faktor tersebut lebih memudahkan tugasnya dalam hal menyelesaikan konflik-konflik yang terjadi, dan menyalurkannya ke arah perkembangan yang positif.

Di samping itu faktor-faktor yang mengharuskan adanya perubahan maupun pengembangan organisasi, perlu pula diketahui 
dan dipahami oleh setiap manajer kontemporer, karena perubahan maupun pengembangan merupakan suatu bagian yang inhaeren dari siklus kelangsungan setiap organisasi. Mempelajari manajemen konflik perubahan — pengembangan, mengharuskan kita untuk juga memahami aspekaspek psikologis, dan aspek-aspek sosiologis, di samping aspek-aspek ekonomi yang berkaitan dengannya.

\section{HASIL DAN PEMBAHASAN}

Konflik berarti adanya oposisi atau pertentangan pendapat antara orang-orang, kelompok-kelompok atau organisasiorganisasi.

Mengingat adanya berbagai macam perkembangan dan perubahan dalam bidang manajemen, maka adalah rasional untuk menduga akan timbulnya perbedaanperbedaan pendapat, keyakinan-keyakinan serta ide-ide.

Di samping itu perlu pula diingat bahwa apabila orang-orang bekerja sama erat satu sama lain dan khususnya dalam rangka upaya mengejar sasaran-sasaran umum, maka cukup beralasan untuk mengasumsi bahwa dengan berlangsungnya waktu yang cukup lama, pasti akan timbul perbedaanperbedaan pendapat antara mereka.

Mengingat bahwa konflik tidak dapat dihindari, maka approach yang baik untuk diterapkan para manajer adalah pendekatan mencoba memanfaatkan konflik demikian rupa, hingga tepat serta efektif untuk mencapai sasaran-sasaran yang di inginkan.

Pendekatan konflik sebagai bagian normal dari perilaku dapat dimanfaatkan sebagai alat untuk mempromosi dan mencapai perubahan-perubahan yang dikehendaki.

\section{Pola konflik menurut G.R. TERRY}

Konflik biasanya mengikuti suatu pola yang teratur, yang terdiri dari empat macam tahapan.

\section{Pertama: timbul suatu krisis tertentu.}

Di sini terlihat adanya bahaya potensial tertentu. Mereka mengancam pengoperasian secara harmonis serta eksistensi organisasi yang bersangkutan.

Mulai terlihat pertentangan paham secara serius.
Kedua: gejala eskalasi ketidaksesuaian paham terjadi.

Konflik yang berlangsung, mulai menarik perhatian pihak manajemen. Dirasakan perlu adanya tindakan-tindakan korektif tertentu, walaupun pada tahapan ini hal tersebut tidak diduga.

Ketiga: konfrontasi menjadi pusat perhatian.

Pada tahapan ini konfrontasi menjadi pusat perhatian. Hal tersebut menyebabkan diadakannya pembicaraan-pembicaraan antara para manajer yang menduduki peringkat lebih tinggi. Pada tahapan ini biasanya disampaikan janji-janji untuk meneliti keluhan-keluhan yang ada, dan kemudian orang mulai menyusun sebuah rencana untuk tindakan selanjutnya.

\section{Keempat: krisis selanjutnya dialihkan dalam} arti.

Dilakukan penelitian tentang apakah keluhan-keluhan yang disampaikan dapat dibenarkan atau tidak. Dipersoalkan proses prosedur-prosedur yang diusulkan untuk kemudian diambil keputusan penerimaan atau penolakan.

\section{Menghadapi Konflik}

Apabila kita (sebagai pihak pimpinan) mengetahui adanya sesuatu konflik, maka sebaiknya pertama-tama kita mengetahui eksistensinya, dan kemudian perlu kita mengidentifikasi orang-orang yang berhubungan dengannya.

Perlu kita meneliti pikiran orang-orang lain, guna mendapatkan kepastian siapa mereka itu, dan janganlah kita beranggapan bahwa kita telah mengetahuinya.

Tabel 1. Sebuah Kontinum Konflik

\begin{tabular}{|l|c|c|}
\hline \multicolumn{1}{|c|}{$\begin{array}{c}\text { Menang atau } \\
\text { Kalah }\end{array}$} & $\begin{array}{c}\text { Berada di } \\
\text { antaranya }\end{array}$ & $\begin{array}{c}\text { Melakukan } \\
\text { Kompromis }\end{array}$ \\
\hline $\begin{array}{l}\text { Berpegang } \\
\text { teguh pada } \\
\text { pendirian }\end{array}$ & $\begin{array}{c}\text { Struktur organ- } \\
\text { isasi berubah }\end{array}$ & $\begin{array}{c}\text { Doronglah pola } \\
\text { interaksi }\end{array}$ \\
\hline $\begin{array}{l}\text { Tindakan ber- } \\
\text { dasarkan tujuan- } \\
\text { tujuan sendiri }\end{array}$ & $\begin{array}{c}\text { Manfaatkanlah } \\
\text { interdependensi } \\
\text { pekerjaan- } \\
\text { pekerjaan }\end{array}$ & $\begin{array}{c}\text { Carilah pemeca- } \\
\text { han dan jangan } \\
\text { menekan pihak } \\
\text { lain }\end{array}$ \\
\hline $\begin{array}{l}\text { Menyalahkan } \\
\text { pihak lain atas } \\
\text { kegagalan atau } \\
\text { kesulitan }\end{array}$ & $\begin{array}{c}\text { Praktekkanlah } \\
\text { upaya menghin- } \\
\text { dari }\end{array}$ & $\begin{array}{c}\text { Pandanglah } \\
\text { situasi dan } \\
\text { problem secara } \\
\text { luas }\end{array}$ \\
\hline
\end{tabular}




\begin{tabular}{|l|c|c|}
\hline $\begin{array}{l}\text { Upayakanlah } \\
\text { untuk mencapai } \\
\text { keuntungan } \\
\text { khusus untuk } \\
\text { saudara sendiri }\end{array}$ & $\begin{array}{c}\text { Ubahlah } \\
\text { susunan dan isi } \\
\text { pekerjaan }\end{array}$ & $\begin{array}{c}\text { Berilah keper- } \\
\text { cayaan ke pada } \\
\text { pihak lain }\end{array}$ \\
\hline $\begin{array}{l}\text { Ancam dan } \\
\text { makilah pihak } \\
\text { lain }\end{array}$ & $\begin{array}{c}\text { Terapkanlah } \\
\text { latihan keter- } \\
\text { ampilan antar } \\
\text { perorangan }\end{array}$ & $\begin{array}{c}\text { Janganlah } \\
\text { mengambil } \\
\text { posisi inisial }\end{array}$ \\
\hline
\end{tabular}

Kita dapat mengasumsi sesuatu kemenangan, sesuatu kekalahan, atau sesuatu kompromis atau sebuah profil antara seperti ditunjukkan pada skema kita.

\section{Lokasi Konflik}

Konflik dapat terjadi antara individuindividu, antara kelompok-kelompok dan antara organisasi-organisasi.

Apabila dua orang individu masing-masing berpegang pada pandangan yang sama sekali bertentangan satu sama lain, dan mereka tidak pernah berkompromi, dan masingmasing menarik kesimpulan-kesimpulan berbeda-beda, dan apabila mereka cenderung bersifat tidak toleran, maka dapat dipastikan akan timbulnya konflik tertentu.

Pola umum yang berkembang adalah sebagai berikut:

Persepsi A tentang perilaku B terhadap A mempengaruhi reaksi A (rencanarencananya serta intensinya) terhadap B. Sebaliknya hal tersebut ditafsirkan oleh B sesuai dengan rencana-rencana serta intensi B terhadap A, dan hal tersebut mempengaruhi reaksi $\mathrm{B}$ terhadap $\mathrm{A}$.

Dengan perkataan lain: persepsi memainkan peranan penting dalampembentukan dan pemeliharaan posisi-posisi konflik. Konflik kelompok bersifat umum, dan hal tersebut mungkin lebih penting dalam bidang manajemen. Konflik macam ini biasanya timbul dalam kondisi-kondisi berikut:

1. dianutnya nilai-nilai baru oleh anggotaanggota kelompok tertentu;

2. sebuah kesulitan atau problem baru, dihadapi oleh kelompok di mana para anggotanya mempersepsinya dengan cara-cara yang berbeda-beda;

3. peranan seorang anggota di luar kelompok tersebut bertentangan dengan peranan anggota tersebut di dalam kelompok itu.
Adakalanya konflik yang timbul, demikian kuat, hingga kelompok semula terpisah menjadi dua buah kelompok yang bersaingan dan yang bertentangan satu sama lain.

Dan biasanya terlihat gejala bahwa sasaran-sasaran yang berkonflik adalah demikian rupa, hingga masingmasing kelompok dalam upaya mereka mencapainya, seringkali mengorbankan kelompok lain.

Seseorang manajer yang bijaksana, yang menghadapi konflik kelompok, akan berupaya untuk menyebarkan keterangan yang menguntungkan mengenai kelompok tertentu kepada kelompok lain (agar mereka lebih mengenal satu sama lain).

la dapat pula berupaya untuk menggantikan anggota-anggota kelompok yang satu dengan anggota-anggota kelompok lain (agar supaya dengan demikian mereka dapat lebih memahami dan menghayati bagaimana kelompok lain itu berpikir dan berperilaku).

Apabila mungkin, is harus pula menunjukkan pihak yang perlu dilawan bersama-sama yang kiranya mengancam kelangsungan hidup kedua kelompok yang ada (dan menyatakan pernyataan bahwa hanya dengan jalan bersatu mereka dapat bertahan).

Selanjutnya dapat dikatakan pula bahwa ada pula konflik yang timbul antara organisasi-organisasi. Sering diketemukan adanya konflik-konflik intra-organisatoris, maupun konflik-konflik ekstra-organisatoris.

\section{Konflik Didalam Organisasi-organisasi}

Konflik muncul, apabila terdapat adanya ketidaksesuaian paham pada sebuah situasi sosial tentang pokok-pokok pikiran tertentu dan/atau terdapat adanya antagonisme-antagonisme emosional.

Konflik-konflik substantif ( Substantive Conflicts ) meliputi ketidaksesuaian paham tentang hal-hal seperti misalnya: tujuantujuan, alokasi sumber-sumber daya, distribusi imbalanimbalan, kebijaksanaankebijaksanaan dan prosedur-prosedur, Berta penugasan pekerjaan.

Konflik-konflik emosional (Emotional Conflicts) timbul karena perasaan-perasaan marah, ketidakpercayaan, ketidaksenangan, takut dan sikap menentang, maupun 
bentrokan-bentrokan kepribadian.

Kedua macam bentuk konflik yang dikemukakan merupakan hal yang tidak dapat dihindari pada organisasi-organisasi.

Perlu diingat bahwa apabila konflikkonflik dapat dimanaje dengan baik, mereka amat bermanfaat dalam hal memajukan kreativitas dan inovasi.

\section{Konflik Destruktif}

Konflik destruktif menimbulkan kerugian bagi individu atau individu-individu dan atau organisasi atau organisasi-organisasi yang terlibat di dalamnya. Konflik demikian misalnya terjadi, apabila dua orang karyawan tidak dapat bekerja sama karena terjadi sikap permusuhan antar perorangan antara mereka (sebuah konflik emosional destruktif) atau apabila anggota-anggota sebuah komite tidak dapat bertindak, karena mereka tidak dapat mencapai persesuaian paham tentang tujuan-tujuan kelompok (sebuah konflik yang substantif destruktif).

Ada banyak keadaan, di mana konflik dapat menyebabkan orang yang mengalaminya mengalami goncangan (jiwa), bagi mereka yang melihat kejadiannya, dan bagi organisasi atau subunit-subunit di mana situasi konflik terjadi, hal tersebut akan menghambat operasioperasinya.

Sangat tidak menyenangkan misalnya, untuk berada daiam bidang kerja sama, di mana dua orang rekan sekerja terus-menerus menunjukkan sikap bermusuhan mereka satu sama lain.

Ada macam-macam kerugian yang ditimbulkan karena konflik destruktif, misalnya beberapa di antara kerugian yang dapat dialami orang-orang yang terlibat di dalamnya meliputi hal-hal berikut:

1. perasaan cemas/tegang (stress) yang tidak perlu, atau yang mencekam;

2. komunikasi yang menyusut;

3. persaingan yang makin menghebat;

4. perhatian yang makin menyusut terhadap tujuan bersama.

Konflik-konflik destruktif yang timbul secara menyeluruh dapat menyebabkan berkurangnya efektivitas individu-individu, kelompok-kelompok dan organisasiorganisasi, karena terjadi gejala menyusutnya produktivitas dan kepuasan.

\section{Konflik Konstruktif}

Lain kisahnya, apabila kita berbicara tentang konflik konstruktif. Maka Konflik ini justru menyebabkan timbulnya keuntungankeuntungan dan bukan kerugian-kerugian bagi individu (atau individu-individu) dan atau organisasi (atau organisasi-organisasi) yang terlibat di dalamnya.

Adapun keuntungan yang dapat dicapai dari konflik demikian adalah:

1. Kreativitas dan inovasi yang meningkat.

Akibat adanya konflik, orang-orang berupaya agar mereka melaksanakan pekerjaan mereka atau mereka berperilaku dengan cara-cara baru yang lebih baik.

2. Upaya yang meningkat (intensitasnya).

Konflik dapat menyebabkan diatasinya perasaan apatis dan is dapat menyebabkan orang-orang yang terlibat dengannya bekerja lebih keras.

3. Ikatan (kohesi) yang makin kuat.

Konflik yang terjadi dengan pihak "luar", dapat menyebabkan diperkuatnya identitas kelompok, diperkuatnya ikatan (kohesi) dan komitmen untuk mencapai tujuan bersama.

4. Ketegangan yang menyusut.

Konflik dapat membantu menyusutnya ketegangan-ketegangan antar pribadi, yang apabila tidak demikian, di "tabung" hingga hal tersebut menyebabkan timbulnya stress.

\section{Memahami Situasi-situasi Konflik}

Penanganan situasi-situasi konflik secara berhasil, memerlukan kemampuan untuk memahami proses-proses serta elemenelemen yang melandasinya.

Perhatikan misalnya contoh berikut:

Presiden sebuah perusahaan kecil, berkeinginan untuk secepatnya mengintroduksi sebuah sistem penyusunan arsip dengan bantuan komputer rnikro. Tetapi, pimpinan bagian akunting, tidak dapat menyetujui ide tersebut..

Jadi, dengan demikian terlihat adanya perbedaan pendapat antara kedua belah pihak, sehubungan dengan kemungkinan perubahan prosedur-prosedur.

Presiden perusahaan tersebut dalam kasus ini merupakan pihak yang prinsipal dalam konflik yang terjadi. 
la juga merupakan pihak atasan pihak prinsipal lain, dipandang dari segi organisatoris.

Ada saja kemungkinan bahwa akuntan tersebut merasa terancam karena cara-cara Presiden perusahaan tersebut menangani situasi yang berkembang.

Konflik yang timbul mungkin bersifat konstruktif dalam hal mengambil keputusan terbaik untuk kepentingan perusahaan tersebut, atau ia dapat menjadi destruktif karena terjadi sikap "permusuhan" dengan seorang karyawan utama.

Faktor-faktor kunci yang perlu dipertimbangkan pada setiap situasi konflik adalah:

- perbedaan-perbedaan tentang fakta-fakta:

- perbedaan-perbedaan tentang metodemetode:

- perbedaan-perbedaan tentang tujuan-tujuan:

- perbedaan-perbedaan tentang nilai-nilai.

Perhatikan selanjutnya tabel berikut yang menunjukkan konflik antara Presiden perusahaan kecil yang telah dikemukakan dengan pimpinan departemen akuntansi.

Setelah kita mengidentifikasi perbedaanperbedaan yang ada, maka alasan-alasan untuk mereka dapat dicari, hingga dengan demikian dapat disusun tindakan-tindakan untuk mengatasinya.

Marilah kasus yang dikemukakan kita pelajari kembali, dan kita akan memperhatikan tindakan-tindakan manajerial yang memiliki potensi guna mengatasi konflik yang ada dengan cara konstruktif.

1.Untuk menyelesaikan perbedaanperbedaan tentang faktafakta.

Informasi yang diperoleh perlu dibagikan: harus dilakukan tindakan untuk mengecek validitas data; lebih banyak data perlu dikumpulkan dari sumbersumber luar yang dipercayai.

2.Untuk menyelesaikan perbedaanperbedaan tentang metodemetode.

Tabel 1: Perbedaan-perbedaan opini tentang sistem pengarsipan yang menggunakan komputer.

\begin{tabular}{|c|c|c|c|c|}
\hline & \multicolumn{4}{|c|}{ SIFAT-SIFAT PFRBEDAAN-PERBEDAAN } \\
\hline & $\begin{array}{l}\text { Tentang fakta- } \\
\text { fakta }\end{array}$ & $\begin{array}{l}\text { Tentang me- } \\
\text { tode-metode }\end{array}$ & $\begin{array}{l}\text { Tentang tujuan- } \\
\text { tujuan }\end{array}$ & $\begin{array}{l}\text { Tentang nilai- } \\
\text { nilai }\end{array}$ \\
\hline Presiden & $\begin{array}{l}\text { Sistem ban ter- } \\
\text { sebut akan meng- } \\
\text { hemat biaya }\end{array}$ & $\begin{array}{l}\text { Sistem itu harus } \\
\text { diinstabisi sege- } \\
\text { ra }\end{array}$ & $\begin{array}{l}\text { Kita mengingin- } \\
\text { h:11 data yang } \\
\text { tepat yang sege- } \\
\text { ra dapat dicapai } \\
\text { apabila dibutuh- } \\
\text { Kan }\end{array}$ & $\begin{array}{l}\text { Efisiensi } \\
\text { merupakan }\end{array}$ \\
\hline $\begin{array}{l}\text { Pimpinan } \\
\text { Departe- } \\
\text { men Akun- } \\
\text { ting }\end{array}$ & $\begin{array}{l}\text { Sistem baru ter- } \\
\text { sebut akan me- } \\
\text { makan lebih ba- } \\
\text { nyak biaya }\end{array}$ & $\begin{array}{l}\text { Kit a harus ber- } \\
\text { gerak perlahan- } \\
\text { lahan }\end{array}$ & $\begin{array}{l}\text { Kita memerlu. } \\
\text { kan sebuah sis- } \\
\text { tem yang di- } \\
\text { manaje oleh } \\
\text { para akuntan } \\
\text { yang dapat } \\
\text { memecahkan } \\
\text { masalah-ma- } \\
\text { salah yang ti- } \\
\text { dak diduga se- } \\
\text { belumnya }\end{array}$ & $\begin{array}{l}\text { Kita perlu } \\
\text { memperiim- } \\
\text { hangkan ke- } \\
\text { sejahteraan } \\
\text { para karya- } \\
\text { wan yang } \\
\text { loyal }\end{array}$ \\
\hline
\end{tabular}

Sasaran-sasaran umum perusahaan perlu diingat; perbedaan paham yang sedang berlangsung harus dianggap sebagai perbedaan-perbedaan tentang alat-alat, dan bukanlah perbedaan tentang tujuan-tujuan; alternatif-alternatif lain di luar sistem yang diotomatisasi, yang diusulkan perlu dipelajari.
3.Guna menyelesaikan
perbedaan-

perbedaan tentang tujuantujuan.

Tujuan-tujuan sang presiden perusahaan dan sang akuntan, pimpinan bagian atau departemen akuntansi perlu dijelaskan; masing-masing tujuan perlu diperbincangkan, dan apabila perlu harus direvisi relatif dibandingkan dengan tujuantujuan yang ingin dicapai oleh perusahaan yang 
bersangkutan.

4.Guna menyelesaikan perbedaan-perbedaan tentang nilai-nilai. Sang presiden perusahaan dan sang akuntan harus saling memahami (share) nilai-nilai mereka tentang fungsi-fungsi penyimpanan arsip; perlu diupayakan untuk mengetahui di mana wilayah tumpang tindihnya nilai-nilai dan yang mengandung konsistensi-konsistensi tertentu.

Andaikata tindakan-tindakan seperti telah dikemukakan berhasil, maka konflik orisinal yang timbul, mungkin akan bersifat konstruktif bagi perusahaan yang bersangkutan.

Mungkin sebagai hasil, akan diinstalasi sebuah sistem komputer baru, yang menyebabkan timbulnya penghematan biaya.
Atau mungkin sistem "manual" dipertahankan, hingga dengan demikian kekeliruan "yang mahal biayanya" dapat dihindari.

Apapun keputusan yang diambil, pemahaman situasi konflik dengan baik, akan menyebabkan bahwa terpenuhi kepentingan terbaik bagi perusahaan yang bersangkutan.

Ada cara lain untuk menganalisis konflik, yaitu menurut tahapan melalui apa konflik tersebut berkembang. Perhatikan gambar 1 berikut.

Apabila kondisi-kondisi demikian terdapat, maka tersedia lahan subur untuk berkernbangnya konflik. Adanya kondisikondisi tersebut, menunjukkan situasi di mana terdapat potensi konflik tinggi.

Gambar 1: Tahapan berkembangnya sesuatu konflik.

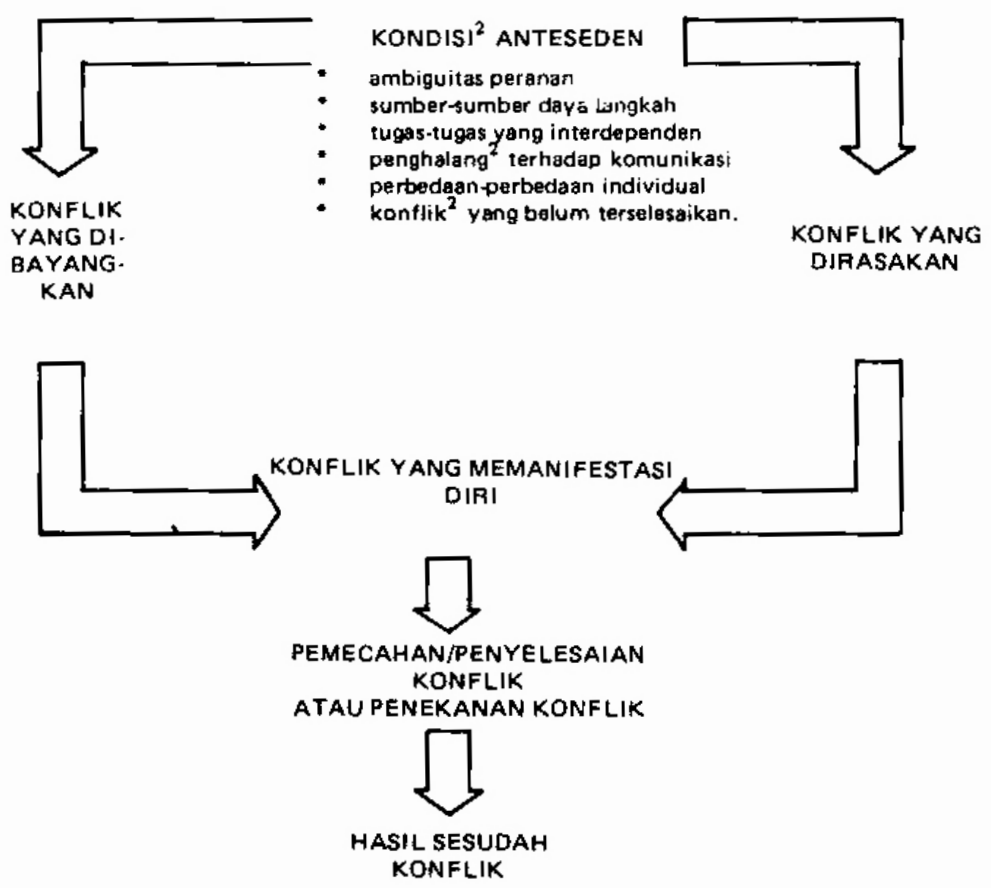

Apa yang dinamakan "konflik yang dibayangkan" (Perceived Conflict), terjadi, sewaktu anteseden-anteseden yang dianggap sebagai dasar bagi timbulnya perbedaan-perbedaan substantif atau emosional antara orang-orang, diketahui.

Sudah tentu, harus diakui, bahwa persepsi tersebut mungkin dirasakan atau tidak oleh orang-orang yang terlibat di dalamnya

Apabila. konflik dirasakan, maka ia mencapai makna dalam arti bahwa cukup banyak tegangan yang terdapat, hingga muncul keinginan untuk mengurangi perasaan yang kurang menyenangkan itu.

Adakalanya, orang-orang merasakan adanya konflik, tetapi, mereka tidak mengetahui dengan pasti apa sumber ataupun penyebabnya.

Konflik yang dinyatakan secara terbuka, dikatakan sebagai konflik yang memanifestasi diri. Sebuah konflik manifes, dapat diatasi, dalam arti bahwa kondisi-kondisi 
anteseden diperbaiki, ditekan, hingga dengan demikian tidak ada perubahan dalam kondisi-kondisi anteseden, dan perilaku konflik dikendalikan.

Akhirnya, basil tentang bagaimana konflik tertentu ditangani, dapat mempengaruhi konflikkonflik masa mendatang. Konflik-konflik yang tidak diatasi, akan berkembang intensitasnya, dan ia akan menimbulkan konflikkonflik masa yang akan datang sehubungan dengan persoalan-persoalan yang serupa.

Pemecahan konflik sebenarnya, menyebabkan timbulnya kondisi-kondisi yang mengurangi potensi untuk konflikkonflik pada masa mendatang, yang serupa sifatnya dan ia juga menyediakan landasan bagi konflik-konflik lainnya untuk diatasi atau dipecahkan dengan cara yang konstruktif.

\section{Penyelesaian Konflik (Conflict Resolution).}

Konflik dapat dihadapi dengan cara:

- bersikap tidak acuh terhadapnya:

- menekannya atau

- menyelesaikannya.

Sikap tidak acuh berarti bahwa tidak adanya upaya langsung untuk menghadapi sebuah konflik yang telah termanifestasi.

Maka, dalam keadaan demikian, konflik dibiarkan berkembang menjadi sebuah kekuatan konstruktif atau sebuah kekuatan destruktif.

Menekan sebuah konflik yang terjadi, (Suppression), menyebabkan menyusutnya dampak konflik yang negatif, tetapi is tidak mengatasi, ataupun meniadakan pokokpokok penyebab timbulnya konflik tersebut.

la hanya merupakan sebuah pemecahan semu (Surface Solution), yang menyebabkan kondisi-kondisi anteseden, yang merupakan penyebab orisinal terjadinya konflik tetap ada.

Penyelesaian konflik (Conflict Resolution) hanya terjadi, apabila alasanalasan latar belakang terjadinya sesuatu konflik ditiadakan dan tidak disisakan kondisi-kondisi yang menggantung atau antagonisme-antagonisme untuk penyebab timbulnya lagi konflik pada masa mendatang.

1. Aneka macam gaya manajemen konflik.

Gaya atau pendekatan seseorang dalam hal menghadapi sesuatu situasi konflik dapat diterangkan sehubungan dengan tekanan relatif atas apa yang dinamakan 62
"Cooperativeness" dan "Assertiveness". "Cooperativeness" adalah keinginan untuk memenuhi kebutuhan dan minat pihak lain. "Assertiveness" adalah keinginan untuk memenuhi keinginan dan minat diri sendiri.

Perhatikan gambar berikut yang menunjukkan lima macam gaya manajemen konflik dan timbul karena aneka macam keinginan yang disebut sebelumnya dalam situasi-situasi konflik.

\section{Gambar 2: Lima macam gaya manajemen konflik.}

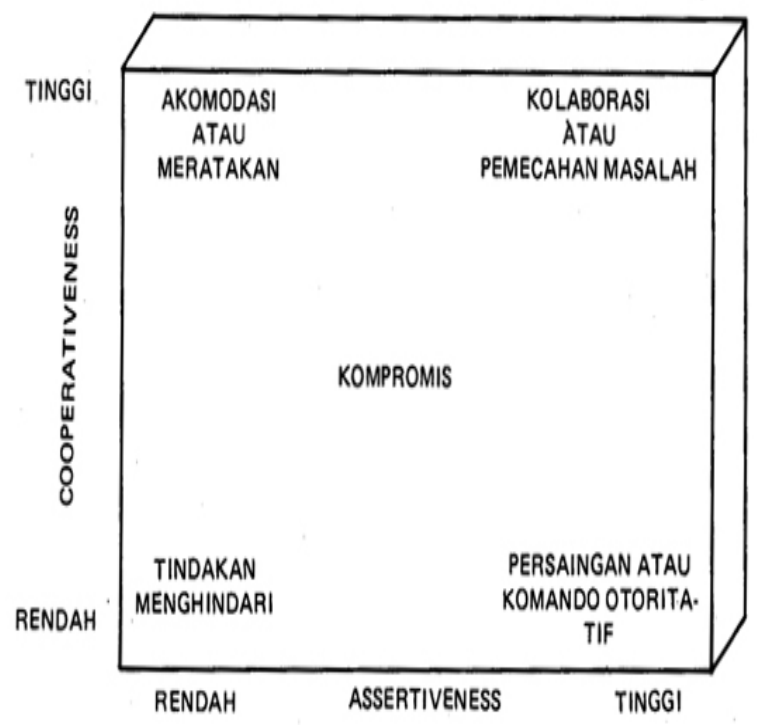

Adapun gaya dan intensi yang diwakili masing-masing gaya sebagai berikut:

1. Tindakan menghindari

Bersikap tidak kooperatif, dan tidak asertif; menarik din dan situasi yang berkembang, dan atau bersikap netral dalam segala macam "cuaca"

2. Kompetisi atau komando otoritatif

Bersikap tidak kooperatif, tetapi asertif; bekerja dengan cara menentang keinginan pihak lain, berjuang untuk mendominasi dalam suatu situasi "menang-atau-kalah", dan atau memaksakan segala sesuatu agar sesuai dengan kesimpulan tertentu, dengan menggunakan kekuasaan yang ada.

3. Akomodasi atau meratakan

Bersikap kooperatif, tetapi tidak asertif; membiarkan keinginan pihak lain menonjol; meratakan perbedaan-perbedaan guna mempertahankan harmoni yang diciptakan secara buatan. 


\section{Kompromis}

Bersikap cukup kooperatif dan asertif, tetapi tidak hingga tingkat ekstrim. Bekerja menuju ke arah pemuasan kepentingan parsial semua pihak yang berkepentingan; melaksanakan upaya tawar-menawar untuk mencapai pemecahan-pemecahan "akseptabel" tetapi bukan pemecahan optimal, hingga tak seorang pun merasa bahwa is menang atau kalah secara mutlak.

5. Kolaborasi (kerjasama) atau pemecahan masalah

Bersikap kooperatif, maupun asertif; berupaya untuk mencapai kepuasan benarbenar setiap pihak yang berkepentingan, dengan jalan bekerja melalui perbedaan-perbedaan yang ada; mencari dan memecahkan masalah demikian rupa, hingga setiap orang mencapai keuntungan sebagai hasilnya.

\section{KESIMPULAN}

Dalam gaya manajemen konflik seperti dilukiskan pada gambar sebelumnya, menunjukkan hasil-hasil yang berbeda-beda

Mereka terutama menunjukkan perbedaan dalam hal menimbulkan hasil:

1. kalah-kalah;

2. menang-kalah;

3. menang-menang.

Hal tersebut adalah penting, oleh karena penyelesaian konflik yang baik hanya terjadi dalam kasus "menang-menang".

1. Konflik "kalah-kalah".

Konflik kalah-kalah terjadi, apabila tak seorang pun di antara pihak yang terlibat mencapai keinginannya yang sebenarnya, dan alasan-alasan mengapa terjadinya konflik tidak mengalami perubahan.

Sekalipun sebuah konflik kalah-kalah seakan-akan terselesaikan atau memberi kesan lenyap untuk sementara waktu, is mempunyai tendensi untuk muncul kembali pada masa mendatang.

Hasil kalah-kalah, biasanya akan terjadi, apabila konflik dimanaje dengan sikap menghindari, akomodasi, meratakan dan atau melalui kompromis.

Sikap menghindari merupakan sebuah bentuk ekstrim tiadanya perhatian (Non Attention). Setiap orang berpura-pura seakanakan konflik tidak ada dan mereka hanya berharap bahwa konflik tersebut akan terselesaikan dengan sendirinya.Akomodasi atau meratakan menekan perbedaanperbedaan antara pihak yang berkonflik, dan menekankan persamaan-persamaan dan bidangbidang kesepakatan. Koeksistensi damai melalui diakuinya kepentingan bersama, merupakan tujuan yang ditekankan. Tindakan meratakan (Smoothing), mungkin sekali tidak menghiraukan esensi real konflik tertentu.

"Marilah kita berkompromi (di negara kita "musyawarah untuk mencapai mufakat") seringkali terdengar sebagai ungkapan dalam situasi konflik. Kompromis akan terjadi, apabila dibuat akomodasi demikian rupa, hingga masingmasing pihak yang berkonflik, mengurbankan hal tertentu yang dianggap mereka sebagai hal yang bernilai.

Maka, akibatnya adalah bahwa tidak ada sate pihak pun yang mencapai keinginan mereka sepenuhnya, dan diciptakan kondisi kondisi anteseden untuk konflik-konflik yang mungkin akan muncul pada masa yang akan datang.

2. Konflik "Menang-Kalah".

Pada konflik "menang-kalah", salah satu pihak mencapai apa yang diinginkannya dengan mengorbankan keinginan pihak lain.

Hal tersebut mungkin disebabkan karena adanya persaingan, di mana orang mencapai kemenangan melalui kekuatan, keterampilan yang superior, atau karena unsur dominasi.

la juga dapat merupakan hasil dari komando otoritatif, sewaktu seorang otoritas formal mendiktir sebuah pemecahan dan kemudian dispesifikasinya apa yang akan dicapai dan apa yang akan dikorbankan dan oleh siapa.

Andaikata figur otoritas tersebut merupakan pihak aktif di dalam konflik yang berlangsung, maka kiranya mudah untuk meramalkan siapa yang akan menjadi pemenang dan siapa yang akan kalah. Mengingat bahwa strategi-strategi menang-kalah juga tidak memecahkan kausa pokok terjadinya konflik, maka kiranya pada masa mendatang konflikkonflik akan muncul lagi.

3. Konflik "Menang-Menang".

Konflik "menang-menang" diatasi dengan jalan menguntungkan semua pihak yang terlibat dalam konflik yang bersangkutan.

Hal tersebut secara tipikal dicapai, apabila 
dilakukan konfrontasi persoalan-persoalan yang ada, dan digunakannya cara pemecahan masalah untuk mengatasi perbedaan-perbedaan pendapat dan pandangan.

Pendekatan positif tersebut terhadap konflik berkaitan dengan perasaan pada pihak-pihak yang sedang berkonflik bahwasa ada sesuatu hal yang salah, dan hal itu perlu mendapatkan perhatian.

Kondisi-kondisi "menang - menang" meniadakan alasan - alasan untuk melanjutkan atau menimbulkan kembali konflik yang ada, karena tidak ada hal yang dihindari ataupun ditekankan. Semua persoalan-persoalan yang relevan diperbincangkan dan dibicarakan secara terbuka. Batu uji akhir untuk menilai sesuatu pemecahan menang-menang, adalah apakah pihak yang turut berpartisipasi di dalam konflik tersebut, bersedia bercakap-cakap satu sama lain.

1. Saya menginginkan sebuah pemecahan yang sekaligus mencapai tujuan-tujuan saudara dan tujuan-tujuan saya sendiri, dan yang dapat diterima oleh kita bersama.

2. Adalah tanggung jawab kolektif kita untuk bersikap .terbuka, dan jujur tentang faktafakta, pendapat-pendapat dan perasaanperasaan.

Pemecahan masalah dan kerja sama (kolaborasi) merupakan pendekatan yang paling berhasil untuk mengatasi konflik.

\section{DAFTAR PUSTAKA}

Adizes, Ichak, How to Solve The Mismanagement, MDOR Institute, Los Angeles, 1980.

Bechard R., Organization Development, Strategy and Models, Addison Wesley Publ. Company, Reading Mass., 1969.

Bennis, W.G.; K.D. Benne, R. Chin (eds.), The Planning of Change, Holt, Rinehart \& Winston, New York, 1961.

Berelson, Bernard, Gary A. Steiner, Human Behavior: An Inventory of Scientific Findings, Harcourt Brace \& World, New York, 1985.

Bergen, Garret L., William V. Haney, Organization Relations and Management Action, Mc. Graw-Hill Book Company, New York, 1966.

Blanchard, K., Management of Organizational Behavior, 4th. edition, Prentice Hall of
India, Private Ltd., New Delhi, 1983.

Coleman, James S., Community

Conflict, The Free Press, New York, 1957.

Cohen, Alan R., Stephen L Fink, Herman Gadon, Robin D. Wilits, Effective Behavior in Organizations, Richard D. Irwin Inc., Homewood Illinois, 1980.

Dwivedi, R.S., Human Relations and Organizational Behavior, Oxford \& IBH Publishing Co., New Delhi, 1979.

Flippo, Edwin B., Personnel Management, Mc. Graw-Hill International Book Company, Singapore, 1982.

Gregor, MC., The Human Side of Enterprise, Mc. Graw- Hill, New York, 1960.

Herbert, Theodore T., Dimensions of Organizational Behavior, Mac Millan Publishing Company, Inc., New York,

Herzberg, Frederich, Bernard Mausner, B. 1976.

Hicks, Herbert G., The Management of Organzations, A Systems and Human Resources Approach, 2-nd. edition, Mc. Graw-Hill Book Compan ${ }^{\mathrm{y}}$, New York, 1972.

Koontz, Harold, Heinz Weichrich, Management, Mc. Graw-Hill International Editions, Singapore, 1988.

Krech, David, Richard S. Crutchfield, Egerton L. Ballachay, The Individual in Society, Mc. GrawHill Book Company, New York, 1962.

Likert, Rensis, The Human Organization, Mc. Graw-Hill, Book Company, New York, 1967.

Maier, Norman R.E., Psychology in Industry, 3-d. edition, Houghton Company, Boston, 1965.

Maslow, H., Eupsychian Management, Richard D. Irwin, Homewood, Illinois, 1965.

Massie, Joseph H., John Doublas, Managing, Prentice Hall of India Ltd., New Delhi, 1975.

Michael, Stephen R., Hasley R. Jones, Organization Management, Intext, Educ. Publishers, New York, 1973.

Munn, Norman L., Psychology, 5-th. edition, Houghton Mifflin Company, Boston, 1964.

Osborn, Alex, Creative Thinking, Claphman and Hall, London, 1958.

Ouchi, William, Theory Z - How American 
Business can meet the Japanese Challenge, Addison Wesley, Publishing Company, Reading, Mass., 1981.

Pascale, Richard Tanner, Anthony G. Athos, The Art of Japanese Management, Simon and Schuster, New York, 1981.

Robbins, Stephen P. Managing Organization Conflict, Prentice Hall, Englewood Cliffs, N.J., 1974.

Rotshild, William E, How To Gain (and mantain) The Competitive Advantage $n$ Business, Mc. Graw ${ }^{i}$-Hill Book Company, New York, 1984.

Selye, Hans, The Stress of Life, Mc. Graw-Hill Book Com- pany, New York, 1956.

Sherif, Muzafer, Carolyn W. Sherif, Groups in Harmony andTensions, Octagon, New York, 1966.

Sisk, Henry L. Management and Organization, 3-d. edi- tion, South Western Publishing Company, Cincinnatti, 1977.

Stoner, James A.F., Charles Wankel, Management, 3-d. edition, Prentice Hall International Inc., London, 1986.

Sutermeister, R.A., People and Productivity, Mc. Graw- Hill Book Company, New York, 1963.

Viteles, Morris S., Motivation and Morale, in Industry, W.W. Norton, New York, 1953. 
Volume VII Nomor 1, September 2009

ISSN 1693 - 5128
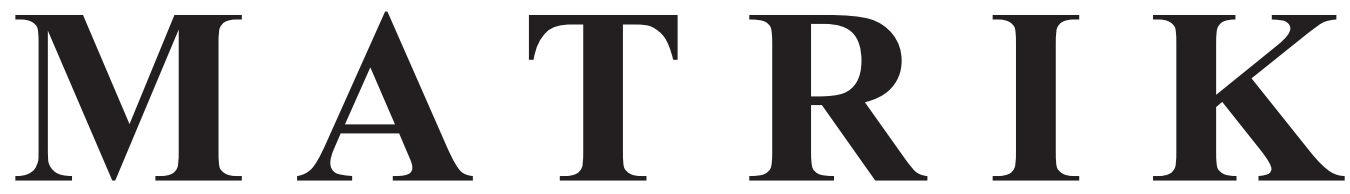

\section{Jurnal Manajemen \& Teknik Industri - Produksi} INDEK SUBJEK

A

analysis factor

analisis hirarki

analitycal hierarchy process

C

change

cleaner production

confict

D

design

development

dominant factor

E

economic

F

faktor

I

identify attribute of quality
K

kualitas

kontribusi teknologi

M

manufacturing resources planning MRP II

$\mathbf{P}$

PPIC

psychological

S

service Quality

sosiologis

T

taguchi

teknometrik 